Leading by example, saving energy and taxpayer dollars in Federal facilities and fleets.

\section{Federal Fleet Requirements}

\section{EPACT and E.0. 13423: How Do Federal Fleets Comply?}

The Federal Fleet initiative is shaped by the requirements of Title III of the Energy Policy Act (EPACT) of 1992, as amended by EPACT of 2005, and Executive Order (E.O.) 13423. Under Title III of EPACT 1992, 75\% of a Federal fleet's covered lightduty vehicle (LDV) acquisitions in U.S. metropolitan areas must be alternative fuel vehicles (AFVs). Agencies receive credits for each light-, medium-, or heavy-duty AFV they acquire each year and for biodiesel (typically used in B20, a blend of 20\% biodiesel, $80 \%$ petroleum diesel) used in fleet vehicles. Table 1 lists the number of credits agencies are awarded for AFVs and biodiesel use.

\section{Table 1. EPACT Credit Structure}

\begin{tabular}{|c|l|}
\hline $\begin{array}{c}\text { Credits } \\
\text { Awarded }\end{array}$ & Situation \\
\hline 1 & $\begin{array}{l}\text { Dual-fuel (flexible or bi-fuel) vehicles, regardless of vehicle size class as long as } \\
\text { the vehicle meets the AFV definition of EPACT 1992, as amended by EPACT } 2005\end{array}$ \\
\hline 2 & Dedicated light-duty AFVs \\
\hline 3 & Dedicated medium-duty AFVs \\
\hline 4 & Dedicated heavy-duty AFVs \\
\hline 1 & $\begin{array}{l}\text { Every } 450 \text { gallons of pure biodiesel (equivalent to 2,250 gallons of B20) used in } \\
\text { diesel vehicles. Caps at } 50 \% \text { of EPACT requirements. }\end{array}$ \\
\hline
\end{tabular}

Section 701 of EPACT 2005 requires Federal agencies to use alternative fuels in fleet dual-fuel vehicles (flexible or bi-fuel) if the fuel is available within five miles or 15 minutes and does not cost more than gasoline on a per-gallon basis.

In addition to Title III and Section 701 requirements, Federal agencies must also comply with E.O. 13423, which was issued by President Bush in January 2007 and revoked E.O. 13149. Under E.O. 13423, agencies are required to:

- Reduce petroleum consumption by $2 \%$ annually through fiscal year (FY) 2015 compared to their FY 2005 baseline value.

- Increase alternative fuel use by at least $10 \%$ compounded annually through FY 2015 compared to their FY 2005 baseline value.

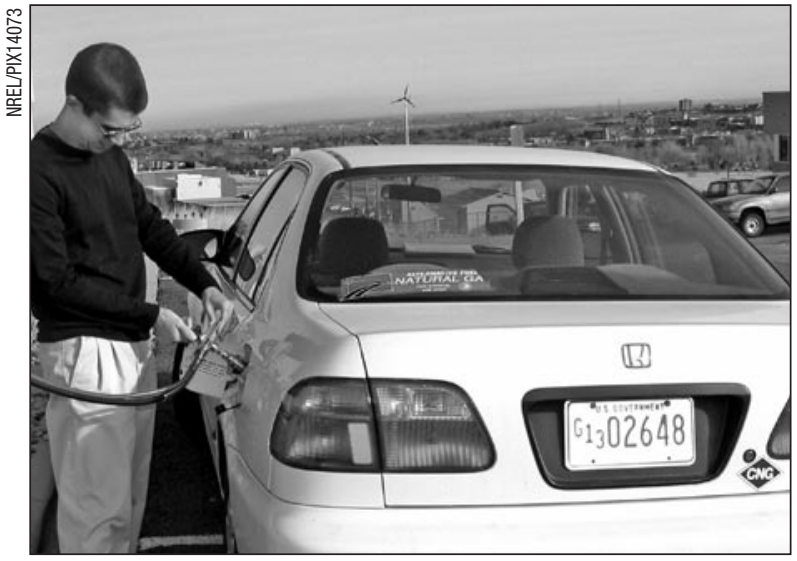

EPACT Section 701 and E.O. 13423 require Federal agencies to use alternative fuel in AFVs. Here, a driver fills a government Honda GX with compressed natural gas.

\section{Who Is Covered?}

Court Services and Offender Supervision General Services Administration

National Aeronautics and Space Administration Smithsonian Institute

Social Security Administration

U.S. Department of Agriculture

U.S. Department of Commerce

U.S. Department of Defense

U.S. Department of Energy

U.S. Department of Health and Human Services

U.S. Department of Homeland Security

U.S. Department of Housing and Urban Development

U.S. Department of the Interior

U.S. Department of Justice

U.S. Department of Labor

U.S. Department of State

U.S. Department of Transportation

U.S. Department of Treasury

U.S. Department of Veterans Affairs

U.S. Environmental Protection Agency

U.S. Postal Service 
- Purchase plug-in hybrids when they are commercially available at a reasonable cost.

Each agency is required to designate a senior-level official responsible for ensuring that his or her agency complies with E.O. 13423. This individual evaluates the agency's strategy for achieving compliance, implements the reporting processes, incorporates the agency's approach in the annual budget submission and standard operating procedures, and assembles the resources needed to meet the goals of E.O. 13423.

\section{Reporting}

To track compliance activity, DOE requires Federal agencies to collect vehicle acquisition, inventory, and fuel-use data from their fleets and report the information to DOE using the Federal Automotive Statistical Tool, an online tracking system accessible at http://fastweb.inel.gov. Each agency is also required to submit an annual report describing its compliance with EPACT and progress made toward the goals outlined in E.O. 13423. This report is due to Congress by Februray 15 and must be published on the agency's Web site (see www.eere.energy.gov/ femp/about/annual_reports.html).

\section{Section 701 Waivers}

Under Section 701 of EPACT 2005, Federal agencies can apply for a waiver from the requirement to use alternative fuel in all agency dual-fuel vehicles if alternative fuel is not available within five miles or 15 minutes of the vehicles' address or the alternative fuel costs more than gasoline on a per-gallon basis.

One consolidated waiver request per covered agency per fiscal year will be considered by DOE. Waivers must be filed by the agency's fleet manager and are due to DOE by June 30 before the fiscal year for which the waiver is requested.

\section{Exemptions}

EPACT 1992 requirements apply to on-road LDVs in fleets of 20 or more vehicles in a Metropolitan Statistical Area or Consolidated Metropolitan Statistical Area (MSA/CMSA) that are capable of being centrally refueled. E.O. 13423 requirements also apply to on-road vehicles but include light-, medium-, and heavy-duty vehicles. However, there are certain exemptions.

\section{For More Information}

\section{EPACT}

www.eere.energy.gov/femp/about/

fleet_requirements.html

Alternative Fuels and Advanced Vehicles

Data Center

www.eere.energy.gov/afdc

Clean Cities

www.eere.energy.gov/cleancities

Fuel Economy Guide

www.fueleconomy.gov

Vehicle Exemptions: EPACT 1992 and E.O. 13423 allow vehicle exemptions for military tactical, lawenforcement, and emergency vehicles. Under EPACT 1992, these vehicles do not count toward the yearly LDV count, which is used to calculate the annual AFV acquisition requirements (75\% of LDVs acquired each year must be AFVs). Under E.O. 13423, petroleum used in these vehicles is exempt.

Fleet Exemptions: Fleet exemptions apply only to the vehicle acquisition requirements of EPACT. Fleets with fewer than 20 vehicles or located outside of an MSA/CMSA are exempt from AFV acquisition requirements. (For a list of covered MSA/CMSAs, see https://apps4.eere.energy.gov/vehiclesandfuels/epact/ state/progs/dyn_msa.cgi.) However, all executive-level Federal agency fleets with 20 or more vehicles are covered under the petroleum reduction and alternative fuel use goals of the executive order (see Who Is Covered?).

All AFVs in covered agencies are covered by Section 701 of EPACT. There are no exemptions for location, fleet size, or vehicle weight.

\section{Infrastructure}

Agencies are directed to work with state, local, and private groups to arrange for AFV fueling at public facilities or support the expansion of public stations. They may also establish alternative fuel stations at agency sites (non-public) if no commercial infrastructure is available in their territory.

For more information on the Federal Fleet Requirements, visit www.eere.energy.gov/femp/ about/fleets.html.
A Strong Energy Portfolio for a Strong America

Energy efficiency and clean, renewable energy will mean a stronger economy, cleaner environment, and greater energy independence for America. Working with a wide array of state, community, industry, and university partners, the U.S. Department of Energy's Office of Energy Efficiency and Renewable Energy invests in a diverse portfolio of energy technologies.

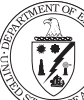

W.S. Department of Energy Energy Efficiency and Renewable Energy

Bringing you a prosperous future where energy is clean, abundant, reliable, and affordable

Produced for the U.S. Department of Energy by the National Renewable Energy Laboratory, a DOE national laboratory

DOE/G0-102008-2632 July 2008 